\title{
PENGUATAN KARAKTER DALAM PENDIDIKAN KELUARGA MENURUT PANDANGAN KI HAJAR DEWANTARA
}

\author{
Oleh : \\ MARSONO \\ Institut Hindu Dharma Negeri Denpasar \\ Email: marsono.65.19@gmail.com
}

\begin{abstract}
ABSTRAK
Ki Hajar Dewantara mengatakan bahwa mendidik anak itulah mendidik rakyat. Keadaan dalam hidup dan penghidupan kita pada jaman sekarang itulah buahnya pendidikan yang kita terima dari orang tua pada waktu kita masih kanak-kanak. Sebaliknya anak-anak yang pada waktu ini kita didik, kelak akan menjadi warga negara kita. Dimaksudkan adalah instuisi pendidikan masih perlu untuk dikembangkan lewat tema-tema pemikiran khusunya. Institusi keluarga yang menjadi lingkungan pendidikan pertama dan utama mendapatkan kriteria utama untuk menempatkan posisi pendidikan sebagai sebuah bangunan untuk menghantarkan manusia menuju cita idealitas pendidikan sebagaimana terumus sebelumnya. Dan pendidikan keluarga tersebutlah yang akan dibahas dalam penulisan ini.
\end{abstract}

Kata Kunci: Pendidikan Keluarga, Penguatan Karakter.

\section{ABSTRACT}

Ki Hajar Dewantara said that educating children is educating the people. The circumstances in our life and our livelihood today are the educational fruits we receive from our parents when we were children. Instead of children who at this time we are educated, will someday become our citizens. Intended is the educational instuition still needs to be developed through the themes of thought, especially. The family institution that became the first and main educational environment received the main criteria for putting the educational position as a building to deliver people to the ideals of educational ideal as previously formulated. And that family education will be discussed in this writing.

Keyword: Family Education, Strengthening Character.

\section{Pendahuluan}

Untuk mendapatkan sistem pengajaran yang akan berfaedah bagi perkehidupan bersama, haruslah sistem ini disesuaikan dengan hidup dan pengidupan rakyat. Oleh karena itu wajiblah kita menyelidiki segala kekurangan dan kekecewaan dalam hidup kita berhubung dengan sifatnya masyarakat yang kita kehendaki. Pengaruh pengajaran itu umumnya memerdekakan manusia atas hidupnya lahir, sedang merdekanya hidup batin itu terdapat dari pendidikan. Manusia merdeka yaitu yang hidupnya lahir atau batin tidak tergantung pada orang lain, akan tetapi bersandar atas kekuatan sendiri. Maksud pengajaran dan pendidikan yang berguna untuk perkehidupan bersama ialah memerdekakan manusia sebagai anggota dari persatuan (rakyat). 
Di dalam hidup merdeka maka seseorang harus senantiasa ingat, bahwa ia hidup bersama-sama dengan orang-orang lain, yang tergolong menjadi suatu bahagian dari persatuan manusia yang juga berhak menuntut kemerdekaannya, dan mereka itu semua lebih besar (rakyat). Dalam penidikan harus senantiasa diingat, bahwa kemerdekaan itu bersifat tiga macam : berdiri sendiri (zelfstanding), tidak tergantung pada orang lain (onafhankelijk), dan dapat mengatur dirinya sendiri (vrijheid, zelfbeschikking). Umumnya pendidikan berarti daya upaya untuk memajukan bertumbuhnya budi pekerti (kekuatan batin, karakter), pikiran (intellect), dan tubuh anak yakni kehidupan dan penghidupan anak-anak yang kita didik searas dengan dunianya.

Sistem pendidikan yang dilangsungkan hari ini tiada lain adalah hasil aktualisasi dari proses pencapaian tujuan pendidikan yang dirumuskan sebelumnya. Penjabaran dalam bentuk kurikulum serta tujuan kondisional tidak terlepas dari garis besar nilai-nilai yang ingin diciptakan sebagai hasil proses pendidikan.

Sistematika dari tujuan pendidkan tiada lain adalah gambaran umum dari cita idealita pendidikan yang harus direalisir lewat program pengajaran dimana khususnya bagi suatu bangsa adalah memiliki tujuan pendidikan yang mendalam dalam masa tertentu. Seperti dalam GBHN merusumuskan tujuan pendidikan nasional adalah bertujuan mencerdasakan kehidupan bangsa dan mengembangkan manusia Indonesai seutuhnya yaitu manusia yang beriman dan bertaqwa terhadap Tuhan Yang Maha Esa dan berbudi pekerti luhur, memiliki pengetahuan yang terampil, kesehatan jasmani dan rohani, kepribadian yang mantap dan mandiri serta rasa tanggung jawab kemasyarakatan dan kebangsaaan.

\section{Pengertian Pendidikan Karakter}

Karakter berasal dari bahasa Yunani yang arti dalam bahasa inggrisnya adalah "to mark" yaitu menandai dan memfokuskan bagaiaman mengaplikasikan nilai kebaikan dalam bentuk tindakan atau tingkah laku, sehingga orang yang tidak jujur, kejam, rakus dan perilaku jelek lainnya dikatakan orang berkarakter jelek. Sebaliknya, orang yang perilakunya sesuai dengan kaidah moral disebut dengan berkarakter mulia.

Karakter menurut Pusat Bahasa Depdiknas adalah bawaan, hati, jiwa, kepribadian, budi pekerti, perilaku, personalitas, sifat tabiat, temperamen dan watak. Sementara itu yang disebut dengan berkarakter ialah kepribadian, berprilaku, bersifat, bertabiat dan berwatak, sedangkan pendidikan dalam arti sederhana sering diartikan sebagai usaha manusia untuk membina, kepribadiannya sesuai dengan nilai-nilai di dalam masyarakat dan kebudayaan.

Karakter merupakan nilai-nilai perilaku manusia yang berhubungan dengan Tuhan Yang Maha Esa, diri sendiri, sesama manusia, lingkungan dan kebangsaan yang terwujud dalam pikiran, sikap, perasaan, perkataan, dan perbuatan berdasarkan normanorma agama, hukum, tata krama, budaya dan adat istiadat. Dalam perkembangannya, istilah pendidikan atau paedagogie, berarti bimbingan atau pertolongan dengan sengaja oleh orang dewasa agar ia menjadi dewasa. Selanjutnya pendidikan diartikan sebagai usaha yang dijalankan seseorang atau kelompok lain agar menjadi dewasa untuk mencapai tingkat hidup atau penghidupan lebih 
tinggi dalam arti mental.

Pendidikan karakter adalah pendidikan budi pekeri puas, yaitu yang melibatkan aspek pengetahuan (cognitive), perasaan (feeling), dan tindakan (action). Menurut Thomas Lickona, tanpa ketiga aspek ini, maka pendidikan karakter idak akan efektif dan pelaksanaannya juga harus dilakukan secara sistematis dan berkelanjutan. Pendidikan karakter adalah upaya yang terencana untuk menjadikan pserta didik mengenal, peduli dan menginternalisasi nilai-nilai sehingga peserta didik berperilaku sebagai insan kamil. Pada pendidikan karakter, yang mau dibangun adalah karakter-budaya yang menumbuhkan kepenasaran intelektual (intellectual curiosity) sebagai modal untuk mengembangkan kreativtias dan daya inovatif yang dijiwai dengan nilai kejujuran dan dibingkai dengan kesopanan dan kesantunan (Dirjen Dikdas: 2012).

Pendidikan karakter, alih-alih disebut pendidikan budi pekerti, sebagai pendidikan nilai moralitas manusia yang disadari dan dilakukan dalam tindakan nyata. Di sini ada unsur proses pembentukan nilai tersebut dan sikap yang didasari pada pengetahuan mengapa nilai itu dilakukan. Dan, semua nilai moralitas yang disadari dan dilakukan itu bertujuan untuk membantu manusia menjadi manusia yang lebih utuh. Nila itu adalah nila yang membantu orang dapat lebih baik hidup bersama dengan orang lain dan dunianya (learning to live together) untuk menuju kesempurnaan. Nilai itu menyangkut berbagai bidang kehidupan seperti hubungan sesama (orang lain, keluarga), diri sendiri (learning to be), hidup bernegara, alam dunia, dan Tuhan. Dalam penanaman nilai moralitas tersebut unsur kognitid (pikiran, pengetahuan, kesadaran) dan unsur afektid (perasaan) juga unsur psikomotor (perilaku). (Muslich, M. 2011: 67)

istilah $\begin{array}{cc}\text { Pendidikan karakter dalam } \\ \text { sederhananya }\end{array}$ pendidikan budi pekerti. Kata karakter berasal dari bahasa inggris, character, artinya watak. Ki Hadjar Dewantara telah jauh berpikir dalam masalah pendidikan karakter. Mengasah kecerdasan budu sunggu baik, karena dapat membangun budipekerti yang baik dan kokoh, hingga dapat mewujudkan kepribadian (persoonlijkhheid) dan karakter (jiwa yang berasas hukumkebatinan). Jika itu terjadi orang akan senantiasa dapat mengalahkan nafsu dan tabiattabiatnya yang asli (bengis, murka, pemarah, kikir, keras dan lain-lain). (Ki Hadjar Dewantara, 1997:24) Selanjutnya Ki Hadjar Dewantara mengatakan yang dinamakan "budi pekerti" atau watak atau dalam bahasa asing disebut "karakter" yaitu "bulatnya jiwa manusia" sebagai jiwa yang "berasas hukum kebatinan". Orang yang memiliki kecerdasan budipekerti itu senantiasa memikir-mikirkan dan merasa-rasakan serta selalu memakai ukuran, timbangan, dan dasar-dasar dengan pasti; yaitu karena watak atau budipekerti itu memang bersifat tetap dan pasti.

Budi pekerti, watak, atau karakter, bermakna bersatunya gerak pikiran, perasaan, dan kehendak atau kamauan, yang menimbulkan tenaga. Ketahuilah bahwa "budi" itu berarti pikiran perasaan kemauan, sedang "pekerti" itu artinya "tenaga". Jadi "budi pekerti" itu sifatnya jiwa manusia, mulai angan-angan hingga terjelma sebagai tenaga. Dengan "budi pekerti" itu tiap-tiap manusia berdiri sebagai manusia merdeka (berpribadi), 
yang dapat memerintah atau menguasai diri sendiri (mandiri, zelfbeheersching). Inilah manusia yang beradab dan itulah maksud dan tujuan pendidikan. Jadi di sini dikatakan bahwa pendidikan itu berkuasa untuk mengalahkan dasardasar dari jiwa manusia, baik dalam arti melenyapkan dasar-dasar yang jahat dan memang dapat dilenyapkan, maupun dalam arti "naturaliseeren" (menutupi, mengurangi) tabiat-tabiat jahat yang "biologis" atau yang tak dapat lenyap sama sekali, karena sudah bersatu dengan jiwa.

Istilah karakter (budi pekerti) erat sekali berhubungan dnegan budaya karena keduanya sama-sama berkaitan dengan akal dan tindakan yang dilakukan oleh manusia dalam hidup bermasyarakat. Karakter (budi pekerti) adalah bagian dari kebudayaan yang mengajarkan tentang kesopanan, moral, tingkah laku dan keluhuran budi yang harus dilakukan oleh seseorang. Budi pekerti adalah keselarasan antara akal dan tindakan. Tindakan yang baik harus dilandasi akal dari hiwa yang sudah masak yang diatur menurut sistem norma dari budaya yang melatar belakangnya. (Dewantara, Hajar, Ki. 1994: 74)

Sedangkan kata pendidikan, $\mathrm{Ki}$

Hadjar Dewantara mengatakan bahwa pendidikan ialah usaha kebudayaan yang bermaksud memberi bimbingan dalam hidup tumbuhnya jiwa raga anak agar dalam kodrat pribadinya serta pengaruh lingkungannya, mereka memperoleh kemajuan lahir batin menuju ke arah adab kemanusiaan. (Suratman, Ki. 1987: 12)

Ki Hadjar Dewantara lebih lanjut menegaskan bahwa pendidikan itu suatu tuntutan dalam hidup tumbuhnya anak-anak. Ini berarti bahwa hidup tumbuhnya anak-anak itu terletak di luar kecakapan atau kehendak para pendidik. Anak itu sebagai makhluk, sebagai manusia, sebagai benda hidup dan tumbuh kodratnya sendiri. Maka apa yang dikatakan kekeuatan kodrati yang ada pada anak itu tidak lain ialah segala kekuatan di dalam hidup batin dan hidup lahir dari anak-anak itu, yang ada karena kekuatan kodrat. Kaum pendidik hanya dapat menuntun tumbuhnya atau hidupnya kekuatankekuatan itu, agar dapat memperbaiki lakunya (bukan dasarnya) hidup dan tumbuhnya itu.

Dari konsepsi tersebut dapat diambil kesimpulan bahwa Ki Hadjar Dewantara ingin; (a) Menempatkan anak didik sebagai pusat pendidikan; (b) Memandang pendidikan sebagai suatu proses yang dengan demikin bersifat dinamis; (c) Mengutamakan keseimbangan antar cipta, rasa, karsa dalam diri anak.

Dengan demikian pendidikan yang dimaksud oleh $\mathrm{Ki}$ Hadjar Dewantara memperhatikan keseimbangan cipta, rasa dan karsa tidak hanya sekedar proses alih ilmu pengetahuan saja atau transfer of knowledge, tetapi sekaligus pendidikan juga sebagai proses transformasi nilai (transformation of value). Dengan kata lain pendidikan adalah proses pembentukan karakter manusia agar menjadi sebanarbenarnya manusia.

Dari konsep diatas dimaksudkan secara umum pendidikan karakter adalah pola untuk membentuk masyarakat yang beradab, membangun watak manusia yang berketuhana yang maha esa, merdeka lahir batin, luhur akal budinya, cerdas dan memiliki keterampilam, sehat jasmani dan rohani, sehingga bisa mewujudkan manusia yang mandiri serta bertanggung jawab terhadap 
kesejahteraan bangsa, negara, dan masyarakat pada umumnya.

Pandangan Ki Hadjar

Dewantara tentang Pendidikan

Karakter menunjukkan kepada kita bahwa jauh hari Ki Hadjar Deantara memiliki komtmen yang tinggu untuk membentuk karakter bangsa melalui pendidikan. Hanya sayangnya pada perkembangannya pendidikan justru kehilangan roh dan semangatnya, sehingga terjebak pada pencapaian target sempit, sehingga perwujudan karakter bangsa yang baik menjadi terabaikan.

\section{Makna Pendidikan Menurut Ki Hajar Dewantara}

Pendidikan Menurut Ki Hajar Dewantara merupakan proses pembudayaan yakni suatu usaha memberikan nilai-nilai luhur kepada generasi baru dalam masyarakat yang tidak hanya bersifat pemeliharaan tetapi juga dengan maksud memajukan serta memperkembangkan kebudayaan menuju ke arah keluhuran hidup kemanusiaan. Menurut $\mathrm{Ki}$ Hajar Deantara, pendidikan dimulai sejak anak dilahirkan dan berakhir setelah meninggal dunia. Mendidik anak itu sama dnegan mendidika masyarakat karena anak itu bagian dari masyarakat. Mendidik anak berarti mempersiapkan masa depan anak untuk berkehidupan lebih baik, demikian pula dengan mendidik masyarakat berarti mendidik bangsa (Dewantara I, 2004).

Menurut Ki Hadjar, pendidikan adalah pembudayaan buah budi manusia yang beradab dan buah perjuangan manusia terhadap dua kekuatan yang selalu mengelilingi hidup manusia yaitu kodrat alam dan zaman atau masyarakat (Dewantara II, 2004). Dengan demikian, pendidikan itu sifatnya hakiki bagi manusia sepanjang peradabannya seiring perubuhan jaman dan berkaitan dengan usaha manusia untuk memerdekakan batin dan lahir sehingga manusia tidak tergantung kepada orang lain akan tetapi bersandar atas kekuatan sendiri.

Oleh karena itu, kemerdekaan menjadi isu kritis dalam Pendidikan karena menyangkut usaha untuk memerdekakan hidup lahir dan hidup batin manusia agar menusia lebih menyadari kewajiban dan haknya sebagai bagian dari masyarakat sehingga tidak tergantung kepada orang lain dan bisa bersandar atas kekuaan sendiri. Namun, disisi yang lain, kemerdekaan itu bersifat tiga macam, yaitu:

Berdiri sendiri

Tidak tergantung kepada orang lain

Dan dapat mengatur diri sendiri

Dengan demikian, kemerdekaan itu berarti manusia sebagai makhluk individu dan sekaligus sosial dapat mengatur ketertiban hidupnya dalam berhubungan dengan kemerdekaan orang lain (Dewantara I, 2004). Dalam hal ini, Ki Hajar Dewantara membedakan antara sistem "Pengajaran" dan "Pendidikan". Pendidikan adalah tuntutan bagi seluruh kekuatan kodrat yang ada pada anak-anak agar mereka sebagai manusia dan sebagai anggota masyarakat dapat mencapai keselamatan dan kebahagiaan yang setinggi-tingginya. Ibarat bibit dan bua. Pendidik adalah petani yang akan merawat bibit dengan cara menyiangi hulma disekitarnya, memberi air, memberi pupuk agar kelak berbuah lebih baik dan lebih banyak, namun petani tidak mungkin mengubah bibit mangga menjadi berbuah anggur. Itulah kodrat alam atau dasar yang harus diperhatikan dalam pendidikan dan itu diluar kecakapan dan kehendak 
kaum pendidik. Sedangkan pengajaran adalah pendidikan dengan cara memberi ilmu atau pengetahuan agar bermanfaat bagi kehidupan lahir dan batin (Dewantara I, 2004).

Disamping itu, Pengajaran yang tidak berdasarkan semangat kebudayaan dan hanya mengutamakan intelektualisme dan individualisme yang memisahkan satu orang dengan orang lain hanya akan menghilangkan rasa keluarga dalam masyarakat di seluruh Indonesia yang sesungguhnya dan menjadi pertalian suci dan kuat serta menjadi dasar yang kokoh untuk mengadakan hidup tertib dan damai (Dewantara I, 2004). Tiga butir Pengajaran Rakyat menurut Ki Hadjar:

Pengajaran rakyat harus bersemangat keluhuran budi manusia, oleh karena itu harus mementingkan segala nilai kebatinan dan menghidupkan semangat idealisme.

Pengajaran rakyat harus mendidik ke arah kecerdasan budi pekerti, yaitu masaknya jiwa seutuhnya atau character building.

Pengajaran rakyat harus mendidik ke arah kekeluargaan, yaitu merasa bersama-sama hidup, bersama-sama susah dan senang, bersama-sama tanggung jawab mulai dari lingkungan yang paling kecil, yaitu keluarga. Jangan sampai di sistem sekolah umum sekolah menjauhkan anak dari alam keluarganya dan alam rakyatnya.

Oleh karena itu, Pengajaran dan Pendidikan Nasional harus selaras dengan penghidupan dan kehidupan bangsa agar semangat cinta bangsa dan tanah air terpelihara. Dalam hal ini, Ki Hadjar menekankan agar Pendidikan memperhatikan, yaitu:
Kodrat alam

Kemerdekaan

Kemanusiaan

Kebudayaan

Kebangsaan

Pengajaran merupakan salah satu jalan pendidikan yaotu suatu usaha memberi ilmu pengetahuan serta kepandaian dengan latihan-latihannya yang perlu dengan maksud memajukan kecerdasan fikiran (intelek) serta berkembangnya budi pekerti. Ki Hajar Dewantara di bidang pengajaran meletakkan konsep-konsep dasar pengajaran meliputi:

Teori Dasar-Ajar

Trisakti Jiwa

Sistem Among

Ki Hajar Dewantara, pendidik asli Indonesia melihat manusia lebih pada sisi kehidupan psikologisnya. Menurutnya manusia memiliki daya jiwa yaitu cipta, karsa dan karya. Pengembangan manusia seutuhnya menuntut pengembangan semua daya secara seimbang. Pengembangan yang terlalu menitikberatkan pada satu daya saja akan menghasilkan ketidakutuhan perkembangan sebagai manusia. Beliau mengatakan bahwa pendidikan yang menekankan pada aspek Intelektual belaka hanya akan menjauhkan pesarta didik dari masyarakatnya. Dan ternyata pendidikan sampai sekarang ini hanya menekankan pada pengembangan daya cipta, dan kurang memperhatikan pengembangan oleh rasa dan karsa. Jika berlanjut terus akan menjadikan manusia kurang humanis dan manusiawi.

Menurut Ki Hajar Dewantara, metode pendidikan yang cocok dengan karakter dan budaya orang Indonesia dengan karakter dan budaya orang Indonesia tidak memakai syarat paksaan. Orang Indonesia termasuk ke dalam bangsa timur. Bangsa yang 
hidup dalam khazanah nilai-nilai tradisional berupa kehalusan rasa, hidup dalam kasih sayang, cinta akan perdamaian, persaudaraan, serta menghargai kesetaraan derajat kemanusiaan dengan sesama. Nilainilai itu disemai dalam dan melalui dunia pendidikan sejak usia dini anak. Dalam praksis penyamaian nilai-nilai itu, pendidik menempatkan peserta didiknya sebagai subjek, bukan objek pendidikan. Artinya ialah, peserti didik disini diberi ruang seluas-luasnya untuk melakukan eksplorasi potensipotensi dirinya dan kemudian berekspresi secara kreatif, mandiri dan bertanggung jawab. Pendidik adalah orang yang menuntun proses pengekspresian potensi-potensi diri peserta didiknya agar terarah dan tidak deskriktif bagi diri dan sesamanya.

Jadi, Pendidikan memiliki kekuatan untuk melakukan perubahan guna membangun bangsa secara sistematis dan sistemik ke arah yang lebih baik dengancara melihat keadaan yang tidak dikehendaki saat ini dan kemudian menentukan tujuan serta langkah yang dibutuhkan untuk mewujudkan masyarakat yang dikehendaki di masa yang akan datang sebagai koekasi terhadap kesalahan yang telah diperbuat di masa lalu dan harapan digantungkan agar kehidupan yang akan datang yang lebih menyenangkan, lebih demokratis, lebih merakyat dan lebih manusiawi dibanding yang ada sekarang (Dewantara I, 2004) sekaligus menjadi ultimate goal Pendidikan Ji Hadjar Dewantara yaitu,

Hamemayu

\section{Hayuning Manungso.}

Penguatan Karakter dalam

Pendidikan Keluarga Menurut

Pandangan Ki Hadjar

Dewantara.

Yang dinamakan "keluarga" yaitu kumpulnya beberapa orang yang karena terikat oleh satu turunan lalu mengerti dan merasa bediri sebagai satugabungan yang khak, dan berkehendak juga bersama-sama memperteguh gabungan iu untuk kemuliaan satu-saunya dan semua anggotanya. Didalam persatuan keluarga itu si bapak dan si ibulah yang menjadi ketua, si bapak mendapat bagian urusan umum dan yang mengenai perhubungan dengan dunia luar, si ibu beridri sebagai ketua tentang segala urusan didalam hidup keluarga. Walaupun pada umumnya, si bapak itu berdiri sebagai "ketua umum", akan tetapi terdapat juga kadang-kadang si ibu yang memegang tali kekuasaan keluarga, boleh jadi menurut adat istiadat atau berhubung dengan urusan khusus.

Adanya dua orang ketua didalam satu badan penguasa itu tidak usah mengkhawatirkan untuk langsung dan kekalnya tertib damai dalam alam keluarga, oleh karena kedua ketua itu merasa bersatu dan merasa keduaduanya terperintah oleh satu pemerintah yang tak terlihat. Sekarang sebaliknya, keadaan pendidikan yang hanya disandarkan pada aturan "pengajaran" dengan sistem sekolah". Adanya suatu bentuk "intellektualisme" yang sering kali berjauhan dnegan adat kemanusiaan. Anak-anak perempuan maupun lakilaki terasingkan dari hidup keluarga, yang sebenarnya harus menjadi "alam persediaan" atau "tangga" untuk masuk ke alam masyarakat, atau alam kemanusiaan. Mereka tidak suka mengindahkan lagi atau seringkali mengabaikan dengan terang-terangan, bahkan kadang-kadang mrendakan kedua orang tuanya, lalu sikap itu terlihat juga terhadap pada adat kebangsaanya dan kepada rakyatnya.

Anak-anak kita pada jaman kini gemar sekali pada segala 
kesenangan yang berhubungan dengan alam sekolahnya, sehingga keperlua keluarga biasanya dikalahkan. Tiap hari mereka kurang bergaul dengan keluarganya, karena di dalam rumahnya merasa mempunyai alam sendiri, yakni alam "intellektualisme". Bahkan ada hari liburan ahadpun mereka tidak dapat menghabiskan waktu dengan kedua oang tuanya, akan tetapi malah meninggalkan rumah sehari seperti pada hari-hari biasanya. Nyata disini bahwa anakanak itu tidak dapat merasakan cinta kasih kedua orang tuanya dengan secukupnya, perasaan mana sebenarnya amat berfaedah untuk pendidikan kebathinan.

Pengaruh hidup keluarga itu terus menerus dialami oleh anak-anak, lebih-lebih di dalam waktu "govoelige periode" atau "masa peka", yaitu antara umur 31/2 sampai 7 tahun; mudah kita dapat mengerti bahwa budi pekerti tiap-tiap orang itu selain menunjukkan pengaruh-pengaruh dari dasar pembawaannya, pun sebagian besar mengandung pula berbagai pengaruh dari segala pengamannya pada waktu ia masih di dalam "masa peka", yakni pada waktu kecilnya antara umur 31/2 sampai 7 tahun itu, di dalam hidup keluarganya masingmasing.

Secara singkat dapatlah disini dijelaskan bahwa "masa peka" itu adalah waktu yang sangat penting dalam hidupnya kanak-kanan waktu tadi, yakni di antara umur 31/2 sampai 7 tahun, boleh dinamakan waktu "terbukanya jiwa" kanak-kanak. Dalam waktu itu kanak-kanak mudah menerima kesan-kesan serta pengaruhpengaruh dari luar jiwanya. Kesankesan dan pengaruh-pengaruh tadi tidak saja menyebabkan bergerak dan bergolaknya jiwa kanak-kanak seara sadar, yakni "bewurs" namun kesan- kesan seta pengaruh-pengaruh tersebut masuk pula ke dalam jiwa kanakkanak secara sangat mendalam, sampai ke dalam dasar-dasarnya jiwa. Disitulah kesan-kesan tadi tetap tersimpan di dalam jiiwa kanak-kanak yang "onderbewust" dan yang samngat mempengaruhi hidup tumbuhnya segala kekuatan di dalam jiwa kanakkanak.

Untuk membuktikan besarnya pengaruh tadi, dari hidup keluarga terhadap bertumbuh dan berkembangnya watak atau budipekerti di dalam jiwanya kanakkanak. Terdapatlah disitu diantaranya bahwan dari 778 keluarga yang tersangkut anggota-anggotanya didalam perkara-perkara kriminil. Artinya yaitu tidak kurang daro $3 / 4$ dari jumlah kejahatan-kejahatan itu dilakukan oleh anak-anak yang berasal dari keluarga-keluarga yang hidup dalam kerusakan moral. Dr, Declory, seorang ahli pendidikan yang termashur dalam jaman kita sekarang, menetapkan bahwa $70 \%$ dari anakanak yang jatuh ke daam jurang kejahatan itu berasal dari keluargakelaurga yang rusak kehidupannya. Dalam hubungan ini kita ketahui bahwa oleh kaum ahli "paedagogi sosial" (ilmu tentang pendidikan masyarakat) sudah ditetapkan amat perlunya memperbaiki hidup keluarga untuk dapat memperbaiki keadaankeadaan di dalam masyarakat.

Keliru sekali apabila orang mengirah bahwa sudah cukup jika anak-anak itu disekolahkan. Dikiranya tak perlu lagi didalam rumah keluarga diadakan syarat-yarat pendidikan. Segala-galanya seolah-olah diserahkan secara borongan kepada guru-guru kanak-kanaknya. Disini orang lupa bahwa kanak-kanak dirumah sekolah hanya 1,5 . Jam saja, sedang sebagian besar daripada hari yang lama itu 
dialami diluar perguruan, yaitu didalam rumah keluarga atau didalam alam pergaulannya dengan anak-anak lain.

Lain daripada itu jangan dilupakan bahwa menurut keadaannya organisasi sekolahan (sifat dan bentuknya) pada jaman sekarang itu nyata sekali, bahwa kewajiban perguruan itu sebagian besar hanyalah mendidik kecerdasan fikiran serta mempelajari berbagai ilmu pengetahuan dan kepandaian. Pendidikan budipekeri seolah-olah hanya sambil lalu saja dilakukan. Malah timbulnya usaha yang dinamakan "pemeliharaan dan gerakan pemuda" pada jaman sekarang itu menurut maksud dan tujuannya tidak lain daripada pengakuan akan kurangnya pendidikan watak di dalam sekolahan. Untuk melengkapkan pendidikan, para ahli menganjuranjurkan "pemeliharaan pemuda", antara lain dengan mengadakan kepanduan, tempat pertemuan, taman pembacaan, taman kesukaan dan lainlain yang semuanya itu dipimpin oleh orang-oranag tua. Begitulah pua para ahli pendidikan juga menganjuranjurkan adanya "gerakan pemuda", agar mereka itu dalam perkumpulannya masing-masing dapat berusaha mendidik diri sendiri. Cukuplah kita ketahui bahwa ada dua macam usah itu memang dnegan senagaj ditujukan untuk melengkapkan pendidikan didalam perguruan, yang pada jaman sekarang dianggap masih dari dari sempurna, malahan belum mencukupi syarat-syarat pendidikan budipekerti atau pendidikan watak. Sekarang para ahli mengakui adanya tiga alam pendidikan, yaitu:

Alam keluarga.

Alam perguruan

Alam pemuda

Dari ke-3 alam tersebut itu, maka kini kita bicarakan alam yang terpenting yakni "alam keluarga" untuk mengetahui pengaruh-pengaruh apa (yang baik dan yang buruk) yang masuk kedalam jiwanya kanak-kanak dan yang berasal dari hidup keluarga itu.

Pusat keluarga inilah yang paling penting. Mulai kecil hingga dewasa anak-anak hidup di tengahtengah keluarganya. Ini berarti bahwa anak-anak itu, baik didalam "masa peka"-nya (dalam periode dimana segala pengalaman bercampur dengan dasarnya jiwa) maupun di dalam periode bertumbuhnya fikiran (ini mengenai kemajuan dari anganangannya serta bertambah-tambahnya pengetahuan) mendapat pengaruh yang sebanyak-banyaknya serta sedalam-dalamnya dari keluarganya masing-masing.

Alam keluarga itu buat tiaptiap orang adalah alam pendidikan yang permualaan. Pendidikan disitu pertama kalinya bersifat pendidikan dari orang tua, yang berkedudukan sebagai guru (penuntun), sebagai pengajar dans ebagai pemimpin pekerjaan (pemberi contoh). Tiga bagian itu dialam hidup keluarga belum terpisah-pisah atau "gedifferentieered", akan tetapi masih bersifat global atau total, menurut kata phsychologi modern.

Kedua kalinya, di dalam keluarga itu anak-anak saling mendidik; inilah nampak terangterangnya di dalam keluarga, apalagi didalam keluarga yang agak besar. Disini teranglah, betapa susahnya pendidikan terhadap anak tunggal didalam keluarga. Dalam ilmu pendidikan amat dipentingkanlah faedah "saling mendidik" itu.

Ketiga kalinya, didalam alam keluarga anak-anak berkesempatan mendidik diri sendiri , karena didalam 
hidup keluarga itu mereka berbeda kedudukannya seperti orang hidup didalam masyarakat yang seringkali terpaksa mengalami macam-macam kejadian, hingga dengan sendiri menimbulkan pendidikan diri sendiri itu.

Orang tua sebagai guru atau penuntun. Pada umumnya kewajiban ayah-ibu ini sudah berlaku sendiri sebagai adat atau tradisi. Janganlah kita mengira, bahwa ibu-bapak yang beradab dan berpengetahuan tinggi saja dapat melakukan kewajiban ini, ibu-bapak dari rakyat didesa-desapun melakukan pendidikan terhadap anakanaknya. Pertama kalinya tiap-tiap makhluk itu mempunyai naluri paedagogis (khewan juga), sednagkan kedua kalinya mereka itu terhadap pada anak-anaknya senantiasa melakukan usaha yang sebaik-baiknya untuk kemajuannya. Seorang penjahat sekalipun umumnya menutupi kejahatannya, jangan sampai terlihat atau ditiru oleh anak-anaknya.

Orang tua sebagai pengajar. dalam hal ini ada perbedaan antara kaum pengajar dengan ibu-bapak. Seorang pengajar mempunyai pengetahuan cukup untuk memberi pengajaran, ia sudah mendapat kecakapan dan kepandaian pula, oleh karena ia telah dapat didikan persediaan untuk menjadi pengajar. seorang ibu atau bapak ada juga yang cakap melakukan pengajaran, asalkan ia mempunyai ilmu yang cukup (kalau bakat atau dasar kita anggap sudah ada, meskipun sebagai instinct saja), akan tetapi haruslah diketahuai, bahwa kepandaian mengajar itu tak berbeda dengan kepandaian lain-lainnya. (Dewantara, 1962: 376).

Orang tua sebagai pemberi contoh. dalam hal ini maka kaum ibu bapak dan kaum guru atau pengajar berdiri sejajar, artinya kedua-duanya sama harganya; boleh jadi seorang guru lebih cakap memberi teladan kepada anak-anak, akan tetapi dapat juga sebaliknya. Kalau kita membicarakan soa teladan ini, maka yang dimaksudkan ialah tenaga yang berfaedah untuk pendidikan; jadi bolehlah soal ini ditujukan earah pendidikan sodial atau "pendidikan kemasyarakatan' seperti tersebut pada pemulaan karangan ini.

Bagaimana caranya rumah sekolaha tau perguruan memberikan contoh tenaga ini akan kita bicarakan dibelakang; sekarang hanya kewajiban keluargalah yang harus kita pentingkan. Dalam hal ini barang tentu kita semua mengetahui bahwa jaman kini adalah jaman spesialisasi, jaman perkhususan, jaman differensiasi, yaitu jamannya orang-orang tidak melakukan sendiri segala pekerjaan, akan tetapi tiap-tiap orang mempunyai pekerjaan, kecakapan, pengetahuan, sungguhpun ini boleh terhitung seuatu kemajuan yang akan dapat menyempurnakan bentuk hidupbersama, akan tetapi jika kita memandangnya dari pendirian pendidikan, maka lalu nemapk akibatnya, yang tidak baik bagi alampendidikan. Dimana differensiasi masuk kedalam hidup keluarga, maka hilanglah kesempatan bagi anak-anak didalam kelaurga itu untuk mencoba kekuatan dan kecakapannya dalam mengerjakan suatu kepandaian. Mereka tak dapat turut bekerja memperbaiki rumah, menanam, menjaga adik-adiknya, memelihara keluarga yang sakit, membuat arang atau kayu dapur, memasak nasi atau sayur atau teh dan sebagainya.

Anak-anak yang biasa turut mengejrakan segala pekerjaan didalam keluarga, dengan sendiri mengalami dan mempraktekkan macam-macam tenaga yang amat banyak faedahnya 
bagi pendidikan budi pekerti (giat, tahan, berani,cerdik, awas, tenangfikiran, berperasaan, eshetis, dsb.). sesungguhnya alam-keluarga itu bukannya pusat pendidikan individuil saja, akan tetapi juga suatu pusat untuk melakukan pendidikan sosial. Untuk jeman sekarang haruslah kepada orang tua melakukan pendidikan itu tidak dengan sendirian atau berpisah dengan pusat-pusat pendidikan lain, tetapi haruslah selalu berhubungan diri dengan para guru dan pengajar. (Dewantara. 1962: 378).

Contoh-contoh tentang adanya watak-watak yang "biologis" dan tak dapat lenyap darijiwa manusia itu ada banyak dan dapat kita lihat juga dalam hidupnya tiap manusia. Misalnya orang yang karena pendidikannya, keadaannya dan pengaruh lain-lainny, sebenarnya harus berbudi demawan, kalau ia memang mempunyai dasar watak kikir, akan selalu kelihatannya watak "kikir" itu. Biasanya semasa ia tdak sempat "berfikir", tentulah tabiatnya "kikir" itu akan selalu kelihatan, setidak-tidaknya kedermawanan orang itu akan berbeda dengan orang yang memang berdasar watak dermawan.

Oleh karena itu, pendidik lalu "berputus asa" karena menganggap bahwa tabiat-tabiat yang biologis itu (hidup perasaan) tidak dapat dilenyapkan sama sekali. Memang benar kecerdasan intilligibel (hidup angan-angan) itu hanya dapat menutupi tabiat-tabiat perasaan yang tidak baik itu, akan tetapi ingat bahwa dengan menguasai diri, asalkan tetap dan kuat adanya, senantiasa ia akan dapat melenyapkan atau mengalahkan tabiat-tabiat biologis yang tidak baik itu. Jadi kalau kecerdasan budi itu sungguh baik, yaitu dapat mengadakan budipekerti yang baik dan kokoh, hingga dapat mewujudkan kepribadian dan karakter (jiwa yang berasas hukum kebathinan), itulah berarti orang akan senantiasa dapat mengalahkan nafsu dan tabiattabiatnya yang asli, yang secara biologis.

\section{Kesimpulan}

Pendidikan karakter adalah pendidikan budi pekeri puas, yaitu yang melibatkan aspek pengetahuan (cognitive), perasaan (feeling), dan tindakan (action). Menurut Thomas Lickona, tanpa ketiga aspek ini, maka pendidikan karakter idak akan efektif dan pelaksanaannya juga harus dilakukan secara sistematis dan berkelanjutan. Pendidikan karakter adalah upaya yang terencana untuk menjadikan pserta didik mengenal, peduli dan menginternalisasi nilai-nilai sehingga peserta didik berperilaku sebagai insan kamil. Pada pendidikan karakter, yang mau dibangun adalah karakter-budaya yang menumbuhkan kepenasaran intelektual (intellectual curiosity) sebagai modal untuk mengembangkan kreativtias dan daya inovatif yang dijiwai dengan nilai kejujuran dan dibingkai dengan kesopanan dan kesantunan (Dirjen Dikdas: 2012).

Pendidikan karakter, alih-alih disebut pendidikan budi pekerti, sebagai pendidikan nilai moralitas manusia yang disadari dan dilakukan dalam tindakan nyata. Di sini ada unsur proses pembentukan nilai tersebut dan sikap yang didasari pada pengetahuan mengapa nilai itu dilakukan. Dan, semua nilai moralitas yang disadari dan dilakukan itu bertujuan untuk membantu manusia menjadi manusia yang lebih utuh. Nila itu adalah nila yang membantu orang dapat lebih baik hidup bersama dengan orang lain dan dunianya (learning to live together) untuk menuju kesempurnaan. Nilai itu menyangkut 
berbagai bidang kehidupan seperti hubungan sesama (orang lain, keluarga), diri sendiri (learning to be), hidup bernegara, alam dunia, dan Tuhan. Dalam penanaman nilai moralitas tersebut unsur kognitid (pikiran, pengetahuan, kesadaran) dan unsur afektid (perasaan) juga unsur psikomotor (perilaku). (Muslich, M. 2011: 67)

istilah $\begin{array}{cc}\text { Pendidikan karakter dalam } \\ \text { sederhananya }\end{array}$ pendidikan budi pekerti. Kata karakter berasal dari bahasa inggris, character, artinya watak. Ki Hadjar Dewantara telah jauh berpikir dalam masalah pendidikan karakter. Mengasah kecerdasan budu sunggu baik, karena dapat membangun budipekerti yang baik dan kokoh, hingga dapat mewujudkan kepribadian (persoonlijkhheid) dan karakter (jiwa yang berasas hukumkebatinan). Jika itu terjadi orang akan senantiasa dapat mengalahkan nafsu dan tabiattabiatnya yang asli (bengis, murka, pemarah, kikir, keras dan lain-lain). (Ki Hadjar Dewantara, 1997:24)

Dalam hal ini, Ki Hajar Dewantara membedakan antara sistem "Pengajaran" dan "Pendidikan". Pendidikan adalah tuntutan bagi seluruh kekuatan kodrat yang ada pada anak-anak agar mereka sebagai manusia dan sebagai anggota masyarakat dapat mencapai keselamatan dan kebahagiaan yang setinggi-tingginya. Ibarat bibit dan bua. Pendidik adalah petani yang akan merawat bibit dengan cara menyiangi hulma disekitarnya, memberi air, memberi pupuk agar kelak berbuah lebih baik dan lebih banyak, namun petani tidak mungkin mengubah bibit mangga menjadi berbuah anggur. Itulah kodrat alam atau dasar yang harus diperhatikan dalam pendidikan dan itu diluar kecakapan dan kehendak kaum pendidik. Sedangkan pengajaran adalah pendidikan dengan cara memberi ilmu atau pengetahuan agar bermanfaat bagi kehidupan lahir dan batin (Dewantara I, 2004).

Disamping itu, Pengajaran yang tidak berdasarkan semangat kebudayaan dan hanya mengutamakan intelektualisme dan individualisme yang memisahkan satu orang dengan orang lain hanya akan menghilangkan rasa keluarga dalam masyarakat di seluruh Indonesia yang sesungguhnya dan menjadi pertalian suci dan kuat serta menjadi dasar yang kokoh untuk mengadakan hidup tertib dan damai (Dewantara I, 2004). Tiga butir Pengajaran Rakyat menurut Ki Hadjar:

Pengajaran rakyat harus bersemangat keluhuran budi manusia, oleh karena itu harus mementingkan segala nilai kebatinan dan menghidupkan semangat idealisme.

Pengajaran rakyat harus mendidik ke arah kecerdasan budi pekerti, yaitu masaknya jiwa seutuhnya atau character building.

Pengajaran rakyat harus mendidik ke arah kekeluargaan, yaitu merasa bersama-sama hidup, bersamasama susah dan senang, bersamasama tanggung jawab mulai dari lingkungan yang paling kecil, yaitu keluarga. Jangan sampai di sistem sekolah umum sekolah menjauhkan anak dari alam keluarganya dan alam rakyatnya.

Alam keluarga itu buat tiaptiap orang adalah alam pendidikan yang permualaan. Pendidikan disitu pertama kalinya bersifat pendidikan dari orang tua, yang berkedudukan sebagai guru (penuntun), sebagai pengajar dans ebagai pemimpin pekerjaan (pemberi contoh). Tiga bagian itu dialam hidup keluarga belum terpisah-pisah atau 
"gedifferentieered", akan tetapi masih bersifat global atau total, menurut kata phsychologi modern.

1. Orang tua sebagai guru atau penuntun.

2. Orang tua sebagai pengajar.

3. Orang tua sebagai pemberi contoh.

Pendidikan anak-anak adalah kewajiban tiap orang tua, hal mana pada jaman dulu berlaku dan pada waktu ini masih juga terdaapt didalam golongan-golongan masyarakat yang masih mempunyai kesempatan untuk pekerjaan pendidikan itu.

\section{Daftar Pustaka}

Dewantara, Ki Hadjar. 1961. I Pendidikan : UST-Press

Hadi, A. Soedomo. 2008. Pendidikan Suatu Pengantar. Surakarta: UNS Press.

Hanurawan, dkk. 2006. Filsafat Pendidikan. Malang. FIP UM.

Koesoema, A, Doni. 2007. Pendidikan Karakter Strategi Mendidik Anak di zaman Global. Jakarta: Grasindo.

Muslich Masnur. 2011. Pendidikan Karakter : UST-Press

Morin, Edgar. 2005. Tujuh Amteri Penting bagi Dunia Pendidikan :

Sahmo, Bartolomeus. 2013. Visi Pendidikan Ki Hadjar Dewantara. Yogyakarta: Kanisius.

Wiyani, Novan Ardy. 2012. Manajemen pendidikan karakter. Yogyakarta: Pedagogia. 